\title{
The Economic Drivers and Environmental Outcomes of the Clean Development Mechanism in Vietnam
}

\author{
Leonard Smith ${ }^{1}$, Paul Dargusch ${ }^{2}$ and Sebastian Thomas ${ }^{1}$ \\ ${ }^{1}$ School of Business, The University of Queensland, Brisbane 4072, Australia \\ ${ }^{2}$ School of Agriculture and Food Sciences, The University of Queensland, \\ Brisbane 4072, Australia
}

\begin{abstract}
The Clean Development Mechanism (CDM) is the principal source of carbon offsets in the global market, and is intended to be a key driver of sustainable development and technical transformation in developing countries. The distribution of CDM projects by country has been skewed, with over $75 \%$ of registered projects having taken place in just four countries, namely China, India, Brazil and Mexico. A change in this pattern of development may be occurring, however, as smaller developing countries become increasingly active in the carbon market. An example of this is the rapid rise in the number of CDM projects based in Vietnam since early 2009. This paper investigates factors contributing to the growth of CDM projects in Vietnam and describes some of the key features of the projects that have been developed. Hydropower projects are found to dominate new CDM project development in Vietnam. It is suggested that CDM project development in Vietnam may be a tool to support domestic energy security rather than being primarily driven by the intended climate change mitigation and sustainable development objectives of the CDM. It is also possible that Vietnam is emulating the development strategy of China, and may serve as a model for other members of the Least Developed Countries group. A country's domestic policy choices are critical in determining its attractiveness as a host country for offset projects, and Vietnam's policy strategies are successfully harnessing synergies between domestic agendas and regulated foreign markets.
\end{abstract}

Keywords: carbon markets, Asia-Pacific, climate policy, CDM, renewable energy

\section{INTRODUCTION}

A point of conjecture in the climate policy debate is whether the instruments of global carbon governance are serving their purpose or - by increasing regulatory complexity - constraining sustainable development and industrial reform in developing countries (IPCC, 2000; Olsen, 2007; Nussbaumer, 2009). Institutional frameworks that minimise these complexities are crucial to securing offset projects, and countries with an effective governance structure and environmental administration are considered attractive investment destinations (Ellis and Kamel, 2007). The 
proliferation of Clean Development Mechanism (CDM) projects has been limited by inadequacies in the regulatory policies of potential host nations (Ellis and Kamel, 2007; Uddin et al., 2009).

The Socialist Republic of Vietnam (hereafter Vietnam) offers an ideal case study for an examination of CDM impact in smaller developing countries. CDM activity in Vietnam began early, and the country was host to one of the first forestry-based projects in the world. However, natural-resource-based project activities have not increased their presence in Vietnam's CDM portfolio, whereas hydro-electricity generation projects have done so substantially. From early 2009 there has been a rapid increase in projects entering the CDM pipeline for Vietnam; the drivers of this increase warrant investigation.

This paper identifies the factors that drive the development and implementation of CDM projects in Vietnam, and examines the extent to which supportive regulatory systems are likely to encourage positive sustainability outcomes as well as increased foreign investment. The importance in the CDM market of public sector entities, including the United Nations Environment Program (UNEP) Capacity Development for the Clean Development Mechanism, funded by the Dutch Government (Uddin et al., 2009), is also highlighted. This program has had a marked impact on international interest in Vietnam as a potential host for CDM projects, and thus on the country's ability to secure sources of overseas funding (Greiner and Michaelowa, 2003). This paper identifies political economic factors that have influenced the rapid growth of CDM project activity in Vietnam, and thereby sheds light on the actions that have not been taken to promote natural resource-based activities.

After an explanation of the research methodology the paper presents the characteristics of CDM project development in Vietnam to date. Thereafter, key themes in the broad political economy of CDM development are discussed, including barriers to project development, issues of governance, sustainability outcomes, technical and procedural constraints, and Vietnam's position as a member of the Least Developed Countries (LDC) group. The findings of this research will contribute to the design of effective policy frameworks to attract international investment in sustainable development project activities in developing countries. Similar analysis in the context of China has suggested that the Chinese Government has largely employed the CDM as a useful ancillary source of investment to support, and perhaps legitimize, its development agenda (Thomas et al., 2011). It is possible that Vietnam is seeking to emulate China's development strategy. 


\section{RESEARCH METHOD}

The study assesses the 144 projects in the CDM pipeline ${ }^{1}$ for Vietnam as of 1 March 2011 (Table 1). Data were collected from the UNEP/RisøCentre CDM Pipeline Database (reported in Fenhann, 2011) and publicly available Project Design Documents (PDDs). Several levels of variables were evaluated, including: (1) the characteristics of the project types that have been registered and those that are currently in the pipeline; (2) the actors involved in the projects according to their countries of origin and industry sector; and (3) the sustainability of the projects in terms of triple bottom line outcomes.

Data relating to the first and second of these variables were considered through frequency counts and trend analysis. The evaluation of the third variable involved examination of PDDs and an extensive literature review that provided evidence to support the discussion of political economic factors driving project development and government policy reform.

In this analysis, emission reductions are measured in metric tons of carbon dioxide equivalent, or $\mathrm{tCO}_{2} \mathrm{e}$, usually expressed in thousands (or $\mathrm{ktCO}_{2} \mathrm{e}$ ).

\section{RESULTS}

Of these 144 projects 33 were registered, with 100 projects at the validation stage. There were six projects that had had their validation terminated, and one project that had been rejected ${ }^{2}$. Over $71 \%$ of all projects were hydro-electricity activities providing renewable energy to the grid (and the proportion is increasing, with $78 \%$ of projects at validation being of this type). The other prominent project type is avoidance of methane emissions, representing about $12 \%$ of projects. These activities mostly involve recovery of methane in wastewater treatment, and are expected to account for 15000-20000 t of emission reductions from CDM projects in Vietnam to 2020 (Figure 1 provides a summary of the types of CDM projects in Vietnam as of March 2011). There were 144 projects in the CDM pipeline for Vietnam as of 1 March 2011 (as shown in Table 1).

\footnotetext{
${ }^{1}$ Projects 'in the pipeline' include those at validation, requesting registration, with review requested, rejected, and registered.

2 This project involved renovations in a brewery to increase energy efficiency, and was rejected because of failure by the DOE and project participant to apply accurately the baseline and additionality calculations and to provide historical data requested by the CDM Executive Board (UNFCCC, 2009).
} 
Table 1. CDM projects in Vietnam by stage 'in the pipeline' as on 1 March 2011

\begin{tabular}{|c|c|c|c|c|c|c|c|c|}
\hline Project type & そ疍 & 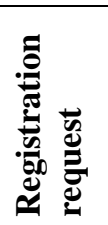 & 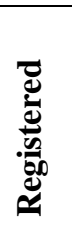 & 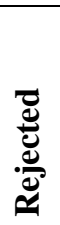 & 莺 & 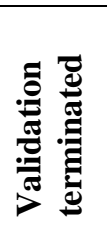 & Total & Total (\%) \\
\hline $\begin{array}{l}\text { Renewable } \\
\text { energy: } \\
\text { hydropower }\end{array}$ & 78 & 2 & 20 & & 1 & 2 & 103 & 71.53 \\
\hline $\begin{array}{l}\text { Methane } \\
\text { avoidance }\end{array}$ & 14 & & 7 & & & 2 & 23 & 12.43 \\
\hline Biomass energy & 3 & & 1 & & & & 4 & 2.47 \\
\hline Landfill gas & 1 & 1 & 2 & & & & 4 & 2.53 \\
\hline EE industry & & & & 1 & & 1 & 2 & 1.30 \\
\hline $\begin{array}{l}\text { EE own } \\
\text { generation }\end{array}$ & 1 & & & & & 1 & 2 & 1.32 \\
\hline $\begin{array}{l}\text { Renewable } \\
\text { energy }\end{array}$ & 1 & & 1 & & & & 2 & 1.33 \\
\hline $\begin{array}{l}\text { Renewable } \\
\text { energy: } \\
\text { solar }\end{array}$ & 2 & & & & & & 2 & 1.35 \\
\hline $\begin{array}{l}\text { Afforestation/ } \\
\text { Reforestation }\end{array}$ & & & 1 & & & & 1 & 0.68 \\
\hline $\begin{array}{l}\text { Fugitive } \\
\text { emissions }\end{array}$ & & & 1 & & & & 1 & 0.69 \\
\hline Total & 100 & 3 & 33 & 1 & 1 & 6 & 144 & 100.00 \\
\hline
\end{tabular}

Eighty-one of the 144 projects employ small-scale methodologies (see Table 2). Three types of projects can be defined as small-scale under the CDM: (1) renewable energy activities that generate less than 15MW; (2) energy efficiency improvement; and (3) other project activities that reduce anthropogenic emissions by sources. This last includes afforestation and reforestation projects that generate up to 16000 tonnes of emissions annually averaged over the project lifetime (UNFCCC, 2011). Smallscale projects use simplified procedures in renewable energy projects (Ornetzeder and Rohracher, 2006), and are subject to less thorough scrutiny than large-scale projects (Madeleine et al., 2008).

As illustrated in Figure 1, two methodologies account for the bulk of anticipated emission reductions. The largest amount of reductions derives from the small-scale methodology AMS-I.D. ('Grid connected renewable electricity generation') which is employed by most small-scale hydro-electricity projects. The volumes of expected reductions from various project types are shown in Table 3. 
Table 2. Number of projects per methodology

\begin{tabular}{|c|c|c|c|c|}
\hline Methodology & $\begin{array}{l}\text { Methodology } \\
\text { type }\end{array}$ & Title of Methodology & $\begin{array}{l}\text { Number } \\
\text { of } \\
\text { projects }\end{array}$ & $\begin{array}{l}\text { Relative } \\
\text { frequency } \\
\text { of projects } \\
(\%) \\
\end{array}$ \\
\hline ACM0001 & Consolidated & $\begin{array}{l}\text { Consolidated baseline and } \\
\text { monitoring methodology for landfill } \\
\text { gas project activities --- Version } 11\end{array}$ & 3 & $2.08 \%$ \\
\hline ACM0002 & Consolidated & $\begin{array}{l}\text { Consolidated methodology for grid- } \\
\text { connected electricity generation } \\
\text { from renewable sources --- Version } \\
11\end{array}$ & 50 & $17.54 \%$ \\
\hline ACM0006 & Consolidated & $\begin{array}{l}\text { Consolidated methodology for } \\
\text { electricity generation from biomass } \\
\text { residues --- Version } 10\end{array}$ & 1 & $0.43 \%$ \\
\hline ACM0010 & Consolidated & $\begin{array}{l}\text { Consolidated methodology for GHG } \\
\text { emission reductions from manure } \\
\text { management systems --- Version } 5\end{array}$ & 1 & $0.43 \%$ \\
\hline ACM0012 & Consolidated & $\begin{array}{l}\text { Consolidated baseline methodology } \\
\text { for GHG emission reductions from } \\
\text { waste energy recovery projects --- } \\
\text { Version } 3.2\end{array}$ & 1 & $0.43 \%$ \\
\hline ACM0014 & Consolidated & $\begin{array}{l}\text { Mitigation of greenhouse gas } \\
\text { emissions from treatment of } \\
\text { industrial wastewater --- Version } 3.1\end{array}$ & 3 & $1.29 \%$ \\
\hline AM0005 & Large-scale & $\begin{array}{l}\text { Small grid-connected zero-emission } \\
\text { renewable electricity generation }\end{array}$ & 1 & $0.44 \%$ \\
\hline AM0009 & Large-scale & $\begin{array}{l}\text { Recovery and utilization of gas from } \\
\text { oil wells that would otherwise be } \\
\text { flared or vented --- Version } 4\end{array}$ & 1 & $0.44 \%$ \\
\hline AM0024 & Large-scale & $\begin{array}{l}\text { Methodology for greenhouse gas } \\
\text { reductions through waste heat } \\
\text { recovery and utilization for power } \\
\text { generation at cement plants --- } \\
\text { Version } 2.1\end{array}$ & 1 & $0.44 \%$ \\
\hline AM0025 & Large-scale & $\begin{array}{l}\text { Avoided emissions from organic } \\
\text { waste through alternative waste } \\
\text { treatment processes --- Version } 11\end{array}$ & 1 & $0.44 \%$ \\
\hline AMS-I.C. & Small-scale & $\begin{array}{l}\text { Thermal energy production with or } \\
\text { without electricity --- Version } 1\end{array}$ & 7 & $3.11 \%$ \\
\hline AMS-I.D. & Small-scale & $\begin{array}{l}\text { Grid connected renewable electricity } \\
\text { generation --- Version } 15\end{array}$ & 55 & $25.52 \%$ \\
\hline
\end{tabular}


Table 2. (Cont.)

\begin{tabular}{|c|c|c|c|c|}
\hline Methodology & $\begin{array}{l}\text { Methodology } \\
\text { type }\end{array}$ & Title of Methodology & $\begin{array}{l}\text { Number } \\
\text { of } \\
\text { projects }\end{array}$ & $\begin{array}{l}\text { Relative } \\
\text { frequency } \\
\text { of projects } \\
\text { (\%) }\end{array}$ \\
\hline AMS-II.D. & Small-scale & $\begin{array}{l}\text { Energy efficiency and fuel } \\
\text { switching measures for industrial } \\
\text { facilities --- Version } 12\end{array}$ & 1 & $0.61 \%$ \\
\hline AMS-III.D. & Small-scale & $\begin{array}{l}\text { Methane recovery in animal manure } \\
\text { management systems --- Version } 16\end{array}$ & 1 & $0.62 \%$ \\
\hline AMS-III.E. & Small-scale & $\begin{array}{l}\text { Avoidance of methane production } \\
\text { from decay of biomass through } \\
\text { controlled combustion, gasification } \\
\text { or mechanical/thermal treatment --- } \\
\text { Version } 16\end{array}$ & 1 & $0.62 \%$ \\
\hline AMS-III.H & Small-scale & $\begin{array}{l}\text { Methane recovery in wastewater } \\
\text { treatment --- Version } 14\end{array}$ & 15 & $9.38 \%$ \\
\hline AR-AMS01 & $\begin{array}{l}\text { Small-scale } \\
\text { A/R }\end{array}$ & $\begin{array}{l}\text { Simplified baseline and monitoring } \\
\text { methodologies for small-scale } \\
\text { afforestation and reforestation } \\
\text { project activities under the clean } \\
\text { development mechanism } \\
\text { implemented on grasslands or } \\
\text { croplands --- Version } 5\end{array}$ & 1 & $0.69 \%$ \\
\hline
\end{tabular}

Table 3. Expected emission reductions to 2020 by project type

\begin{tabular}{lcc}
\hline Project type & $\begin{array}{c}\text { Expected emission reductions } \\
\text { to 2020 (in ktCO2e) }\end{array}$ & $\begin{array}{c}\text { Expected reductions as } \\
\text { \% of total }\end{array}$ \\
\hline Afforestation/ reforestation & 1 & $0.72 \%$ \\
Biomass energy & 4 & $2.88 \%$ \\
EE industry & 2 & $1.44 \%$ \\
EE own generation & 2 & $1.44 \%$ \\
Fugitive emissions & 1 & $0.72 \%$ \\
Landfill gas & 4 & $2.88 \%$ \\
Methane avoidance & 22 & $15.83 \%$ \\
Renewable energy & 1 & $0.72 \%$ \\
Renewable energy: hydro & 101 & $72.66 \%$ \\
Renewable energy: solar & 1 & $0.72 \%$ \\
\hline Total & 139 & 1 \\
\hline
\end{tabular}


CDM activity in Vietnam commenced slowly (Nguyen et al., 2010) and began to accelerate in 2009, with a substantial increase in hydropower projects entering the pipeline from that period (Figure 2 and Figure 3).

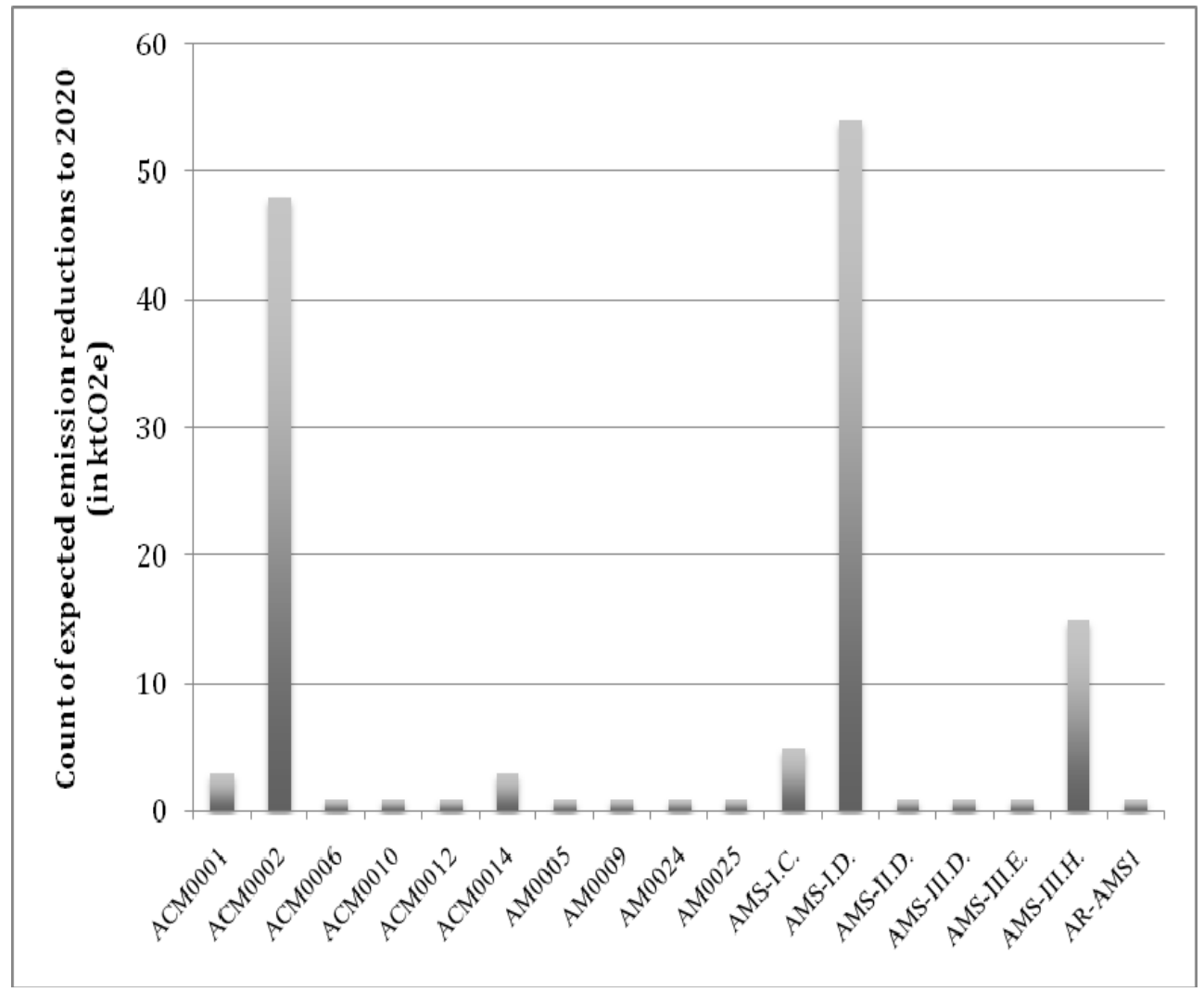

Figure 1. Expected emission reductions from CDM projects in Vietnam to 2020 


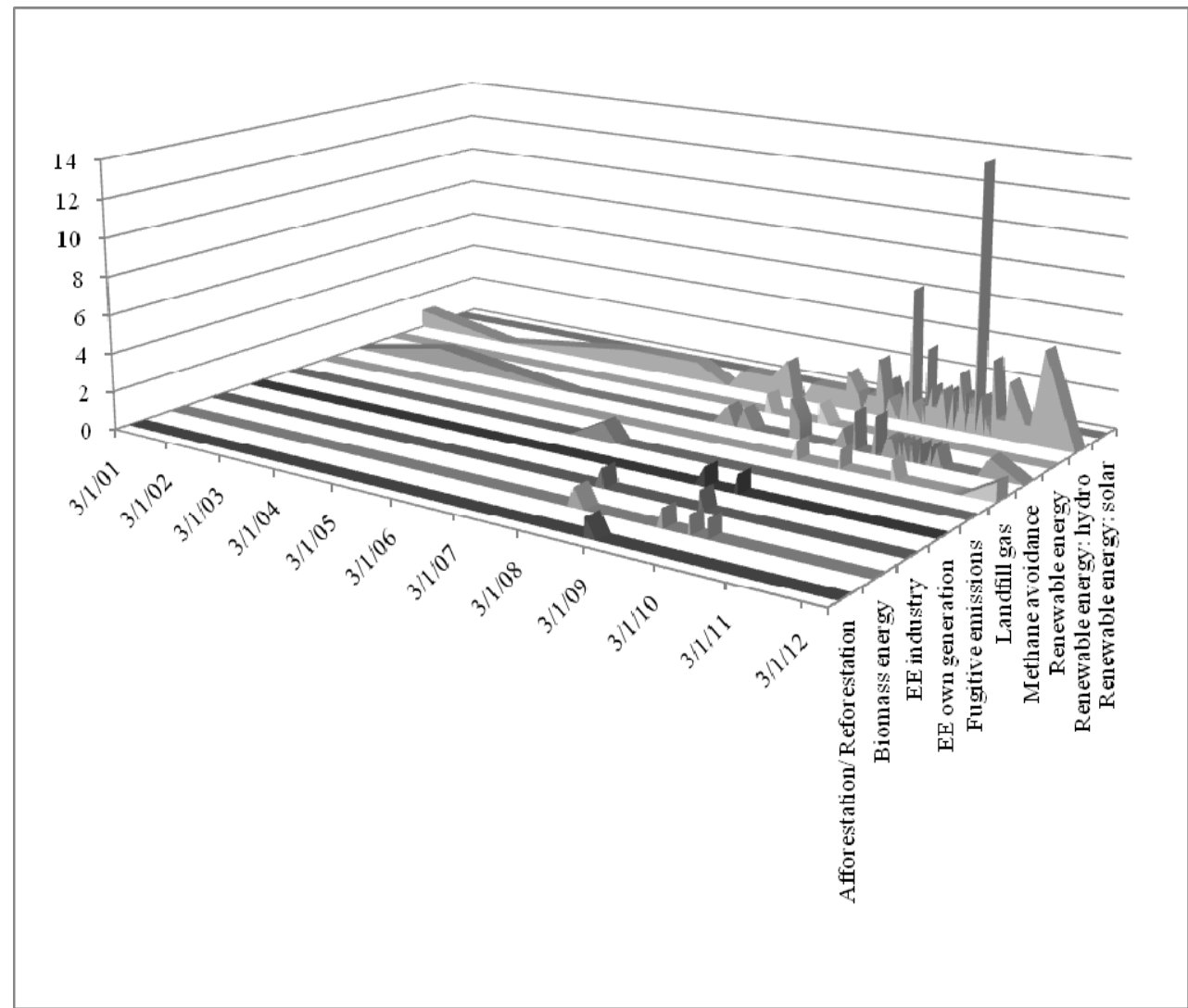

Figure 2. Registration or credit start date of projects in Vietnam by type (by project frequency) 


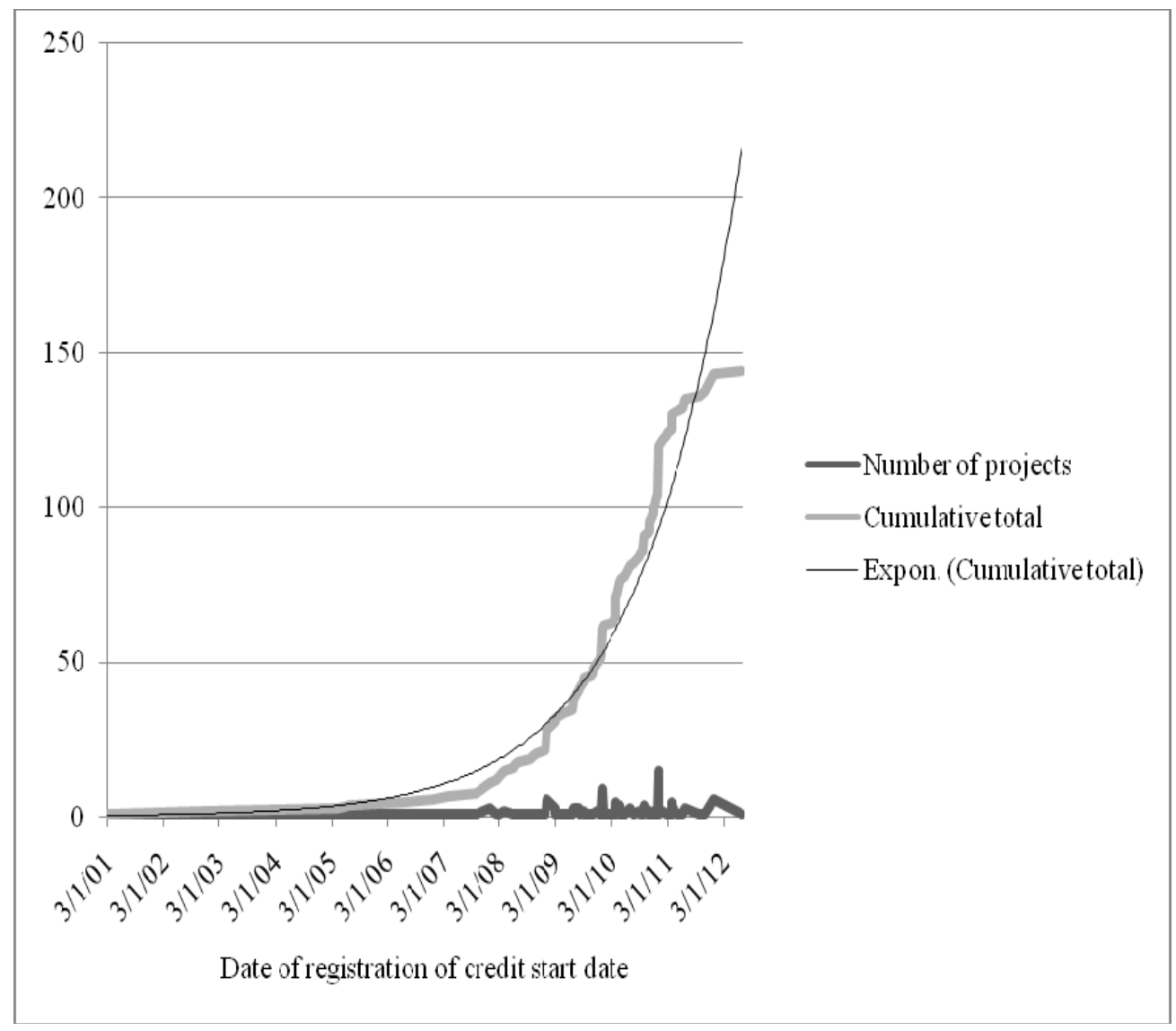

Figure 3. Number of CDM projects in the pipeline in Vietnam, showing exponential trend

Foreign investors in CDM projects in Vietnam are almost entirely private sector organisations, with only one project receiving investment from the Asian Development Bank (Table 4). Foreign partner companies represent a range of nationalities, with Swiss and UK firms holding the largest shares at $18 \%$ and $15 \%$ of the Vietnam CDM market respectively. Firms considered to be 'international' include very large transnational corporations, and these represent investment in $10 \%$ of projects. 
Table 4. Origins of investors in projects by type

\begin{tabular}{|c|c|c|c|c|c|c|c|c|c|c|c|c|c|}
\hline Project type & 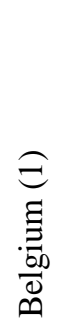 & 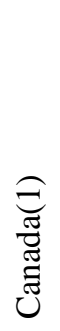 & 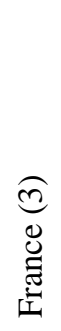 & 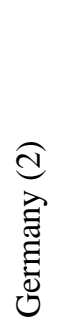 & 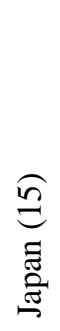 & 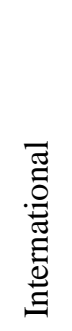 & 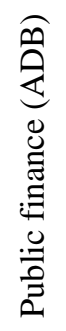 & 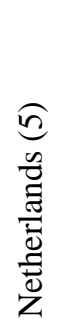 & 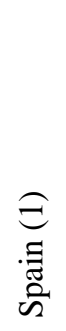 & 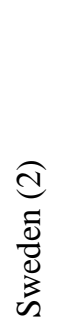 & 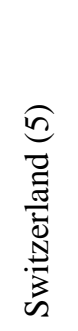 & $\underset{\underbrace{}}{\stackrel{\Xi}{\Xi}}$ & 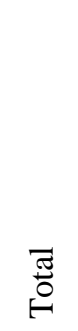 \\
\hline $\begin{array}{l}\text { Afforestation/ } \\
\text { reforestation }\end{array}$ & & & & & & 1 & & & & & & & 1 \\
\hline $\begin{array}{l}\text { Biomass } \\
\text { energy }\end{array}$ & & 1 & & 1 & & 1 & & & & & 1 & & 4 \\
\hline EE industry & & & & & 2 & & & & & & & & 2 \\
\hline $\begin{array}{l}\text { EE own } \\
\text { generation }\end{array}$ & & & & 2 & & & & & & & & & 2 \\
\hline $\begin{array}{l}\text { Fugitive } \\
\text { emissions }\end{array}$ & & & & & 1 & & & & & & & & 1 \\
\hline Landfill gas & & & 1 & & & 2 & & & & & & 1 & 4 \\
\hline $\begin{array}{l}\text { Methane } \\
\text { avoidance }\end{array}$ & & & 1 & 1 & 6 & 2 & 1 & 6 & & & 4 & 2 & 23 \\
\hline $\begin{array}{l}\text { Renewable } \\
\text { energy }\end{array}$ & & & & & & & & & 1 & & & 1 & 2 \\
\hline $\begin{array}{l}\text { Renewable } \\
\text { energy: hydro }\end{array}$ & 1 & & 3 & 8 & 10 & 17 & & 5 & & 6 & 32 & 21 & 103 \\
\hline $\begin{array}{l}\text { Renewable } \\
\text { energy: solar }\end{array}$ & & & & & 1 & 1 & & & & & & & 2 \\
\hline Total & 1 & 1 & 5 & 12 & 20 & 24 & 1 & 11 & 1 & 6 & 37 & 25 & 144 \\
\hline $\begin{array}{l}\text { Relative } \\
\text { frequency }\end{array}$ & $1 \%$ & $0 \%$ & $2 \%$ & $4 \%$ & $7 \%$ & $10 \%$ & $0 \%$ & $5 \%$ & $0 \%$ & $3 \%$ & $18 \%$ & $15 \%$ & $100 \%$ \\
\hline
\end{tabular}

\section{DISCUSSION: THE POLITICAL ECONOMY OF CDM PROJECT} DEVELOPMENT IN VIETNAM

Vietnam is a socialist republic that is open to international trade and is an active member of international organizations, participating in efforts to realise global sustainability goals (EIA, 2007). Economic reform resulting from mounting internal financial pressures commenced in 1986, since which time Vietnam's Gross Domestic 
Product (GDP) has continued to grow. The government regards foreign investment as an appealing means to further the growth of the Vietnamese economy (Kumar and Bhattacharya, 2003).

As shown in Figure 4, CDM project activity in Vietnam has dramatically increased since early 2009. There were 100 projects at validation stage in the CDM pipeline in Vietnam as of 1 March 2011, of which 78 were hydropower projects and 14 were methane avoidance projects. At the same time there were 1147 projects at validation stage in China, 969 of which were registered (Fenhann, 2011). CDM projects in China represent more than half the global total and generate more than two thirds of all certified emission reductions (Fenhann, 2011). This demonstrates that Vietnam is a comparatively small player in the CDM market globally (Heggelund, 2006). At the same time, the ratio of projects at validation to those already registered (the recent acceleration in project activity) indicates that Vietnam's ability to attract investment interest has substantially increased.

Previous research has considered barriers to CDM project development in Vietnam, and found that the principal constraints resulting from the country's administrative culture and investment environment include bureaucratic complexity in the approval process and possibly corruption, financial uncertainty for developers, lack of information and local capacity, and constraints relating to the nature of project activities (Nguyen, 2010). Because the CDM is designed to achieve cost-effective emission reductions and simultaneously encourage sustainability outcomes, the analysis also considers how and to what extent reform strategies have encouraged, or are likely to encourage, non-financial benefits. This calculus applies a political economic approach similar to other evaluations of CDM activity in other contexts (Sutter and Parreño, 2007; Nussbaumer, 2009; Thomas et al., 2011).

There are five key themes that characterise the political economy of the CDM in Vietnam: governance, sustainability outcomes, technical requirements, sectoral approaches and Vietnam's role as one of the Least Developed Countries group.

\section{Governance of CDM Projects in Vietnam}

The United Nations Framework Convention on Climate Change (UNFCCC) and the Kyoto Protocol (KP) were ratified by Vietnam on 16 November 1994 and 25 September 2002 respectively (UNFCCC, 2011). The Ministry Of Natural Resources and Environment (MONRE) was assigned by the Vietnamese Government as the Designated National Authority (DNA) for the implementation of the UNFCCC and KP, and a national focal agency for CDM activities (EIA, 2007). Vietnam has also established a CDM National Authority (CNA), which facilitates project applications through streamlined processes and reduced registration times. The activities of this agency minimise transaction costs for project developers, a key factor in investment decisions (Tuyen, 2006; EIA, 2007; Rahman et al., 2010).

Parameters for CDM projects related to Vietnam's electricity grid have been estimated and made available to project developers through the CNA. This provides 
Vietnam with a competitive advantage because these data are not generally accessible (Ornetzeder and Rohracher, 2006; Capoor and Ambrosi, 2009) If these data can be delivered in a timely and efficient manner offset credits (known as certified emission reductions or CERs) can be issued in a comparatively short period, because the efficiency of the verification process can be improved. There is appeal, therefore, for financiers to invest in energy offset projects in Vietnam because there is an increased likelihood that they will realise a positive return on their investments with considerably less lag time between repayment of initial capital outlay. Vietnam has minimised administrative complexities and the financial burdens that are historically associated with the CDM by not only establishing the CNA but also through provision of baseline data to project developers (EIA, 2007). Determination of the baseline is regarded as being the most costly and complex aspect of a PDD, hence having readily available data generally results in reduction of costs for investors (Michaelowa and Fages, 1999; Probase, 2002; Michaelowa ,2003). It has been widely reported that the key aspect of a nation's attractiveness as a CDM host to prospective project developers is minimal transaction costs (Madeleine et al., 2008; Boyd et al., 2009; Hsu et al., 2009). If a host nation is able to minimise transaction costs, the financial viability of a CDM project increases to the extent that payback period is dramatically reduced (Kumar and Bhattacharya, 2003).

\section{Sustainability Outcomes}

The DNA in Vietnam is charged with assessing the sustainability of projects in accordance with national sustainable development criteria (EIA, 2005). The criteria applied by many DNAs have been criticized for lack of transparency and absence of positive sustainability impacts beyond the project boundary (Nussbaumer, 2009). Furthermore, there is little evidence to suggest that compulsory monitoring mandates are being complied with at national levels (Nussbaumer, 2009). It is in this context of uncertain monitoring, that sustainability initiatives, such as the Gold Standard and Community Development Carbon Fund, have emerged as key initiatives globally (Ellis and Kamel, 2007). There were, however, no projects in Vietnam with Gold Standard accreditation at the time of research.

Determining additionality and assessing sustainability from a holistic perspective in small-scale projects is a comparatively simple process (Ellis and Kamel, 2007). This is due to the decrease in the amount of quantitative material that needs to be verified and assessed. The number of administrative practitioners throughout the approvals process is also reduced. Associated complexities are subsequently reduced and this is clearly reflected in the detail provided in the project design documents. Small-scale project documentation is greatly simplified in comparison to the plethora of detail included within large-scale project documents. The dominance of small-scale project activities in Vietnam is testament to the effectiveness of these measures.

At present, the sustainability assessment methods of the MONRE and DNA are susceptible to the uncertain nature of information provided by project proponents 
(Rahman et al., 2010). A more effective and transparent approval process is needed to rectify problems such as baseline establishment and proving additionality in Vietnam (Madeleine et al., 2008). Establishing baselines and proving additionality are integral in applications for CDM approval; however, both processes can be difficult to define in a transparent manner.

The requirement that validation reports include an assessment of the demonstration of additionality represents a desirable step in the context of global transparency and promoting the integrity of the CDM. However, a key difficulty remains. A conflict of interest arises where the validating agency (the designated operational entity or DOE) for a given CDM project is an agency of a government authority of the host nation (Tilt et al., 2008). In China, for example, the DOE for many of the projects being approved is the Chinese Government (Tilt et al., 2008). Where the DOE is a host nation government authority, the potential for bias and compromised integrity of assessment procedures arises, even if all other procedures and guidelines are adhered to. It is essential for the Vietnamese Government to be aware of these issues in consideration of the rapid rate at which project proponents are applying for project approval within the nation. The Vietnamese Government might consider the prospect of attracting significant foreign financial investment initially appealing; however, it would be remiss to prioritise financial motives at the expense of adopting a holistic approach to CDM approvals processes. Adopting transparent assessment methods, understanding the key pitfalls associated with additionality and other subjective and qualitative forms of assessment and considering the sectoral nature of the project proponent will enable the DNA to assess more accurately projects on individual merits.

For Vietnam to be able to efficiently and accurately assess the sustainability credentials of a large number of projects, it will be necessary for the Vietnam Ministry of Natural Resources and Environment (MONRE) to reassess the current concise set of sustainability indicators, which lack sufficient scientific underpinning (Sutter and Parreño, 2007). Poorly designed regulatory frameworks have the potential to create perverse incentives and encourage behaviour with negative sustainability outcomes (Bode and Michaelowa, 2003). MONRE's reassessment of the current set of sustainability indicators will be particularly important to ensure that CDM projects in Vietnam do not have undesirable effects on communities and ecosystems. Vietnam has been described as a country of moderate attractiveness to CDM proponents and this appeal seems likely to increase in the future (Jung 2006). An approvals process that fails to adopt a holistic approach and favours financial factors when assessing the environmental, economic and social ramifications of individual CDM projects could result in projects being approved and receiving funding that detract from the integrity of the CDM (Gomiero et al., 2000). 


\section{Technical Requirements for CDM Development in Vietnam}

Additionality is one of the principal conditions for the eligibility of a project under the CDM (UNFCCC, 2011). Additionality means that emissions are reduced compared to a business-as-usual scenario. In the case of Vietnam, the process of proving additionality can be complex in light of the nature and economic motivations of the project proponents involved with projects that are currently in the application phase (Boyd et al., 2009). Given that hydro-electric power generation projects comprise the majority of projects that are currently in the pipeline for Vietnam, it can be concluded that, historically, many hydropower projects may have merely subsidised an emissions activity and not been additional (Heuberger et al., 2007). If hydropower projects continue to be approved without establishing additionality, the integrity of the CDM on a global scale and the continuation of the mechanism post2012 are likely to be undermined (Heuberger et al., 2007).

The CDM Executive Board (CDM EB) has instructed project verifiers (DOEs) to ensure that validation reports include an assessment of the demonstration of additionality, including documentation (Boyd et al., 2009). Reports that fail to include this information will be deemed incomplete by the CDM EB, essentially stalling any development that the project proponent may have wished to undertake. The requirement to demonstrate additionality emerged as a result of criticism that the CDM had been funding what were deemed to be business-as-usual projects (Boyd et al., 2009).

Technology transfer from developed nations to developing nations is one of the stated objectives of the CDM (Uddin et al., 2009) and is likely to play an integral role in the future development of the CDM (Uddin et al., 2009). Without holistic sustainability assessment criteria for CDM projects, it would seem that technology transfer could be allowed to slip through the cracks created by the bias toward financial outcomes. The issue of technology transfer is highly relevant in Vietnam in light of the reality that the majority of projects are linked to the energy sector. An effective platform from which to assess accurately and efficiently the sustainability of projects in a holistic manner and define the anthropogenic influences at work is likely to lead to the implementation of projects that will promote the dual objectives of the CDM (Karakosta et al., 2009; Thomas et al., 2009). Securing the integrity of the $\mathrm{CDM}$ at a national and international level and promoting the long-term future of similar projects in a post-Kyoto climate policy framework is integral to the longevity of the mechanism (Hsu et al., 2009).

\section{Sectoral Approaches to CDM Development in Vietnam}

The UNEP has attempted to assist with the establishment of GHG emission reduction projects in accordance with the goals of global sustainability and with a 
focus on the energy sector. Vietnam was one of the three countries ${ }^{3}$ in Asia chosen to participate in the project, which represents an enormous boost to the nation's capacity to host CDM projects (Fenhann, 2011). More specifically, the UNEP aims to improve the administrative capacities of LDCs in the context of managing the technical and financial aspects involved in implementing new CDM projects. The UNEP also seeks to provide participating LDCs with a broad understanding of the opportunities presented by the CDM and to develop institutional infrastructure to allow LDCs to formulate and implement CDM projects. Project partner nations such as The Netherlands have been involved from the initial stages and have evolved to become major contributors to the success of the program (Heuberger et al., 2007). The Netherlands Government has extended sizeable financial contributions to the Vietnamese Government that have funded CDM projects emerging in Vietnam (Heuberger et al., 2007).

Heuberger et al. (2007) observed that particular hydropower projects have historically undermined the principles of triple-bottom-line goals and the precautionary approach to environmental systems management. The Three Gorges dam project in China had associated CDM projects on both large and small scales that have been termed 'unsustainable' (Jackson and Sleigh, 2000; Webber and McDonald 2004; Heggelund, 2006; Tilt et al., 2008). Retrospective approvals associated with these projects should have been far more stringent in making sure sustainability goals were not compromised. The implications of sub-standard adherence to principles of sustainable development and triple bottom line goals include the displacement of local communities and the erosion of the economic, environmental and social factors that comprise their respective social fabrics. The implications of poorly administered sustainability guidelines in China set a precedent for CDM management processes, enabling administrations globally to recognise management adaptations that will allow CDM project management to evolve and improve the integrity of the mechanism.

In light of the poor track record of hydropower projects in providing sustainable energy and addressing triple-bottom-line principles, it would be prudent for the Vietnamese Government to exercise caution in its approach to managing approvals of hydropower projects. This is particularly important in Vietnam's case because the majority of hydropower projects currently proposed involve damming of rivers as opposed to run-of-river hydropower. The key difference between the two technologies and associated infrastructure is that projects involving water storage have extensive environmental and ecological impacts (Heggelund, 2006). Dam construction has typically involved displacement of communities and loss of land that has caused substantial social, environmental and ecological damage (Webber and McDonald, 2004; Heggelund, 2006; Tilt et al., 2008). This technological choice calls into question the sustainability of projects that are currently proposed, illustrating that no

\footnotetext{
${ }^{3}$ Cambodia and the Philippines were also included in the CD4CDM within Asia as part of
} Phase I Activities. Bangladesh was included in Phase II Proceedings, initiated in 2006. 
matter how attractive the financial returns may be, the integrity of each project's sustainability outcomes must be considered in the light of more comprehensive criteria.

The representation of biogas (methane avoidance) projects in the portfolio of CDM activity in Vietnam is declining, but still a crucial component in terms of both project numbers and contributions to technical capacity building and sustainable development goals (Rahman et al., 2010). More than half of the investments by firms from the Netherlands are in methane avoidance projects. This correlation can be traced to frameworks established to promote the CDM for LDCs including the Capacity Development for the Clean Development Mechanism (CD4CDM) established by the UNEP.

The near total absence of project activities in forestry and agriculture from the CDM in Vietnam is striking. While these project types face unique barriers relating to the demonstration of additionality and proof of permanence in reductions (Thomas et al. 2010), it is clear that the Vietnamese Government has not implemented regulatory devices to encourage investment in these sectors, as they have done for energy. While biomass-based energy projects constitute the third largest group in the CDM portfolio in Vietnam, they still represent less than $2.5 \%$ of the total. While the government of Vietnam is attempting to introduce policies in the agriculture sector that will improve carbon sequestration through reforestation and tillage practices, CDM projects in these areas are considered unlikely to be successful in reducing emissions owing mainly to the marginal nature of potential reductions (Leisz et al., 2007). Rural smallholders in Vietnam face numerous constraints in attempting to engage with the CDM market, not least of which are the transaction costs involved (Thomas et al., 2010) and it is likely that interest in forestry activities is shifting to Reducing Emissions from Deforestation and forest Degradation Plus (REDD+) schemes (Blom et al., 2010; Phelps et al., 2010).

\section{The Role of Least Developed Countries (LDCs) in the CDM}

Capital flows generated by the CDM are not being uniformly distributed amongst nations that are deemed to be 'least developed countries' (Uddin et al., 2009). China and India are consuming comparatively large proportions of funding owing to the economic viability of projects in these countries. It has been suggested that these nations are motivated to use the CDM primarily as a vehicle for attracting foreign investment and generating economic gain and have largely disregarded the principles of sustainable development that underpin the mechanism (Webber and McDonald, 2004; Thomas et al., 2011). At an international level, the UNFCCC has recognised that in many instances the CDM has not improved the socio-economic status of LDCs (UNFCCC, 2011).

The issue of the substantial number of LDCs not in receipt of CDM capital flows was discussed at COP15 in Copenhagen in 2009 (Rahman et al., 2010). As a result, the CDM EB is looking favourably upon projects proposed in nations other than India 
and China, the two powerhouses in the current market (Rahman et al., 2010). This increases the potential of the CDM whilst promoting technology transfer and sustainable development in LDCs. The CDMEB also aims to ensure that the CDM is available to all developing nations, as opposed to a select, financially strong few, particularly India and China. Consequently, it is possible to attribute the influx of projects in Vietnam in part to the recognition of project developers that there is an increased likelihood of project approval by the EB in Vietnam. This is due to the fact that the country falls under the category of an LDC that has been recognised as not having received adequate economic stimulus through the CDM. This has given rise to the intervention of the UNEP and the launch of the CD4CDM (EIA, 2007; Fenhann, 2010).

Encouraging LDCs to maximise the potential of the CDM is important, given that climate constraints are likely to become more challenging in the future (Capoor and Ambrosi, 2009). Undermining the system's integrity for short-term economic gain will be of little benefit for LDCs. Ensuring the longevity of the CDM's integrity is crucially important to the mechanism being able to promote greater intergenerational equity in LDCs. This will assist the UNFCCC in promoting the CDM to the global market. When assessing Vietnam as a CDM microcosm the longevity of the country's appeal to international investors lies in promoting broader sustainability outcomes and utilizing the transfer of technologies from developed nations.

The global decline in the price of eco-securities is reportedly attributable to perceived regulatory risks on the part of project developers, more broadly foreign stakeholders (Capoor and Ambrosi, 2009). Vietnam is in the fortunate position of receiving the majority of its CDM investment from the energy sector, which is a field accustomed to elements of regulatory risk in carrying out projects (Sieghart, 2009). The appeal of Vietnam to the energy sector, in the context of new project development, lies in the cooperative nature of the Vietnamese Government and the knowledgeable and competent administrative bodies established in the nation (Madeleine et al., 2008; Boyd et al., 2009; Capoor and Ambrosi, 2009). This combination of factors renders Vietnam an attractive and low-risk country in terms of economically viable financial investment by the energy sector.

\section{CONCLUSION}

Several key factors have influenced the increase in the interest of international stakeholders in CDM project development in Vietnam. Government actions to minimise administrative costs have coincided with favourable actions by the CDM Executive Board and resulted in Vietnam possessing marketable characteristics as a CDM host nation. The central issue arising from this analysis is that while the majority of Vietnam's CDM activities are small-scale projects involving gridconnected hydro-electricity generation, with the majority involving the construction of dams rather than run-of-river technology, there is extensive research indicating that 
these types of projects often result in negative social and environmental sustainability outcomes. It remains to be seen whether this will be the case in Vietnam, but is reason for the government to take a precautionary approach to regulatory reform.

There is an almost total absence in Vietnam's CDM portfolio of project activities in the forestry and agriculture sectors. These project types face substantial barriers, yet potentially offer considerable benefits in terms of triple bottom line sustainability outcomes. Vietnam's government has clearly chosen thus far to focus its policy reform efforts on relatively high-yield, cost-effective energy generation activities.

Projects involving avoidance of methane emissions through treatment of wastewater feature prominently in Vietnam's current CDM profile, but the proportion of these projects is declining. This may indicate that while an attractive methodology type based on ease of implementation and economies, biogas capture and avoidance projects are not as cost-effective as other offset activities. This interpretation is supported by the fact that methane avoidance projects represent $12 \%$ of all projects in Vietnam but only $8 \%$ of total expected emission reductions.

Vietnam serves as an example of a nation that is willing to embrace policy reforms that will drive favourable economic outcomes. The Vietnamese approach to developing CDM projects has attracted increased foreign investment in the nation. However, the emerging character of the Vietnamese CDM portfolio is highly asymmetrical, which suggests the possibility that expedient choices are being made to attract the most immediate investment opportunities, at the expense of balanced, longterm strategic approaches.

\section{REFERENCES}

BLOM, B., SUNDERLAND, T. and D. MURDIYARSO. 2010. Getting REDD to work locally: lessons learned from integrated conservation and development projects. Environmental Science and Policy. 13(2): 164-172.

BODE, S. and A. MICHAELOWA. 2003. Avoiding perverse effects of baseline and investment additionality determination in the case of renewable energy projects. Energy Policy. 31(6): 505-517.

BOYD E., HULTMAN, N., ROBERTS, J.T., CORBERA, E., COLE, J., BOZMOSKI, A., EBELING, J., TIPPMAN, R., MANN, P., BROWN, K. and D.M. LIVERMAN. 2009. Reforming the CDM for sustainable development: lessons learned and policy futures. Environmental Science and Policy. 12(7): 820-831.

CAPOOR, K and P. AMBROSI. 2009. State and Trends of the Carbon Market 2009. World Bank, Washington DC.

EIA (ENERGY INFORMATION ADMINISTRATION). 2005. Vietnam: Country Analysis Brief. Washington, DC.

EIA. 2007. Vietnam Country Analysis Brief. http//www.eia.doe.gov/cabs/ Vietnam/Full.html. Accessed 1 May 2010. 
ELLIS, J. and S. KAMEL. 2007. Overcoming Barriers to Clean Development Mechanism. OECD/IEA/UNEP Risø Centre, Roskilde, Denmark.

FENHANN, J. 2011. CDM Pipeline Database. UNEP Risø Centre, Roskilde, Denmark. Available at www.cdm.pipeline.org. Accessed 1 April 2011.

GOMIERO, T., PETTENELLA, D., GIANG, P.T. and P. MAURIZIO. 2000. Vietnamese uplands: environmental and socio-economic perspective of forestland allocation and deforestation process. Environment, Development and Sustainability. 2(2): 119-142.

GREINER, S. and A. MICHAELOWA. 2003. Defining investment additionality for CDM projects-practical approaches. Energy Policy. 31(10): 1007-1015.

HEGGELUND, G. 2006. Resettlement programmes and environmental capacity in the Three Gorges Dam Project. Development and Change. 37(1): 179-199.

HEUBERGER, R., BRENT, A., SANTOS, L., SUTTER, C. and D. IMBODEN. 2007. CDM projects under the Kyoto Protocol: a methodology for sustainable assessment. Experiences from South Africa and Uruguay. Environment, Development and Sustainability. 9(1): 33-48.

IPCC (INTERGOVERNMENTAL PANEL ON CLIMATE CHANGE. 2000. Good Practice Guidance and Uncertainty Management in National Greenhouse Gas Inventories. OECD, Paris.

JACKSON, S. and A. SLEIGH. 2000. Resettlement for China's Three Gorges Dam: socio economic impact and industrial tensions. Communist and Post-Communist Studies. 33(2): 223-241.

JUNG, M. 2006. Host country attractiveness for CDM non-sink projects. Energy Policy. 34(15): 2173-2184.

KARAKOSTA, C., DOUKAS, H. and J. PSARRAS. 2009. Directing Clean Development Mechanism towards developing countries' sustainable development priorities. Energy for Sustainable Development. 13(2): 77-84.

KUMAR, A., BHATTACHARYA, S.C. and H. PHAM. 2003. Greenhouse gas mitigation potential of biomass energy technologies in Vietnam using the long range energy alternative planning system model. Energy. 28(7): 627-654.

LEISZ S.J., RASMUSSEN, K., OLESEN, J.E., VIEN, T.D., ELBERLING, B. and L. CHRISTIANSEN. 2007. The impacts of local farming system development trajectories on greenhouse gas emissions in the northern mountains of Vietnam. Regional Environmental Change. 7(4): 187-208.

MADELEINE, M., BERGQVIST, K., WÅRDH, S., DAS, A. and E.O. AHLGREN. 2008. A techno-economic assessment of rice husk-based power generation in the Mekong River Delta of Vietnam. International Journal of Energy Research. 32(12): 11361150.

MICHAELOWA, A. and E. FAGES. 1999. Options for baselines of the Clean Development Mechanism. Mitigation and Adaptation Strategies for Global Change. 4(2): 167-185.

MICHAELOWA, A. 2003. Transaction costs of the Kyoto Mechanisms. Climate Policy. 3(3): 261-278. 
MONRE (MINISTRY OF NATURAL RESOURCES AND ENVIRONMENT). 2007. Vietnam CDM Project Pipeline. Hanoi.

NGUYEN, N.T., HA-DUONG, M., GREINER, S. and M. MEHLING. 2010. The Clean Development Mechanism in Vietnam: potential and limitations. Carbon and Climate Law Review, accepted September 2010. http://minh.haduong.com/ files/Nguyen.ea-20100118-CDMPotentialVN.pdf. Accessed 1 May 2010.

NUSSBAUMER, P. 2009. On the contribution of labelled certified emission reductions to sustainable development: a multi-criteria evaluation of CDM projects. Energy Policy. 37(1): 91-101.

OECD (ORGANISATION FOR ECONOMIC COOPERATION AND DEVELOPMENT). 2001. Emissions Baselines - Estimating the Unknown. Paris.

OLSEN, H. 2007. The Clean Development Mechanism's contribution to sustainable development: a review of the literature. Climatic Change. 84(1): 59-73.

OLSEN, K. and J. FENHANN. 2008. Sustainable development benefits of Clean Development Mechanism projects. A new methodology for sustainability assessment based on text analysis of the project design documents submitted for validation. Energy Policy. 36(8): 2773-2784.

ORNETZEDER, M. and H. ROHRACHER. 2006. User-led innovations and participation processes: lessons from sustainable energy technologies. Energy Policy. 34(2): 632-642.

PHELPS, J., GUERRERO, M.C., DALABAJAN, D.A., YOUNG, B. and E.L. WEBB. 2010. What makes a 'REDD' country? Global Environmental Change. 20(2): 322332.

PROBASE (Procedures for Accounting and Baselines for JI and CDM projects). 2002. Final Report. Groningen, the Netherlands.

SIEGHART, L.C. 2009. Unilateral Clean Development Mechanism - an approach for a least developed country? The case of Yemen. Environmental Science and Policy. 12(2): 198-203.

SUTTER, C. and J. PARREÑO. 2007. Does the current clean development mechanism deliver its sustainable development claim? An analysis of officially registered CDM projects. Climatic Change. 84(1): 75-90.

THOMAS, S., DARGUSCH, P., HERBOHN, J. and S. HARRISON. 2010. Why are there so few afforestation and reforestation Clean Development Mechanism projects? Land Use Policy. 27(3): 880-888.

THOMAS, S., DARGUSCH, P. and A. GRIFFITHS. 2011. The drivers and outcomes of the Clean Development Mechanism in China. Environmental Policy and Governance. 21(4): 223-239.

TILT, B., BRAUN, Y. and D. HE. 2008. Social impacts of large dam projects: A comparison of international case studies and implications for best practice. Journal of Environmental Management. 90(supp. 3): 249-257.

TUYEN, T. and A. MICHAELOWA. 2006. UNFCCC Kyoto Protocol Clean Development Mechanism Baseline Construction for Vietnam national electricity grid. Mitigation and Adaptation Strategies for Global Change. 11(3): 723-740. 
UDDIN, S.N., TAPLIN, R. and Y. XIAOJIANG. 2009. Sustainable energy future for Vietnam: evolution and implementation of effective strategies. International Journal of Environmental Studies. 66(1): 83-100.

UNFCCC (United Nations Framework Convention on Climate Change). 2009. Review of the project activity \#1516 at the $46^{\text {th }}$ meeting of the CDM Executive Board. Accessed 1 May 2010. http://cdm.unfccc.int/Projects/DB/DNV-CUK 1200406374.33/Rejection/IGUMWP9U8NUCM0PAN2018FLS1SDDHN.

UNFCCC. 2011. Clean Development Mechanism website. www.cdm.unfccc.int. Accessed 1 March 2011.

WEBBER, M. and B. McDonald. 2004. Involuntary resettlement, production and income: evidence from Xiaoliangdi. World Development. 32(4): 673-690. 